УДК 159.9:17.023.34-053.6(045)

doi: $10.15330 / p s .10 .1 .117-122$

Оксана Власова-Чмерук

Національний авіаційний університет, м. Київ

vlasovoksana@gmail.com

\title{
Аліна Юдко
}

Національний авіаційний університет, м. Київ

alina-yudko@ukr.net

\section{ЗВ'ЯЗОК ЗАДОВОЛЕНОСТІ ЖИТТЯМ ЗІ СТАВЛЕННЯМ ДО ГРОШЕЙ У ОСІБ ЮНАЦЬКОГО ВІКУ}

\begin{abstract}
Питання про те, наскільки пережсивання задоволеності життям, відчуття щастя може бути пов'язане з достатком, фінансовим благополуччям людини, здавна є предметом наукових розвідок для економістів, соиіологів та психологів. Актуальність досліджень иієї теми пов'язана зі змінами монетарних цінностей сучасної молоді. В статті представлені результати емпіричного дослідження зв'язку задоволеності життям зі ставленням до грошей у молоді. Описано процедуру дослідження з використанням чотирьох методик: тесту «Індекс задоволеності життям» в адаптації Н. В. Паніної; тесту «Діагностика задоволеності життям» А. Б. Білоусової; опитувальника «Суб'єктивне економічне благополуччя» $B$. А. Хащенко; методики «Шкала грошових уявлень та поведінки» в модифікаиії М. В. Сімків. За результатами емпіричного дослідження встановлено, щуо негативні установки щчодо грошей (грошова одержимість, неадекватне поодження з грошима, сприйняття грошей як інструменту влади $і$ впливу) погіршують емочійний компонент задоволеності життям (настрій), знижують задоволеність життям у сфері кохання. Економічний оптимізм, спокійне $і$ зважене ставлення до грошей, відчуття того, щзо власний достаток відповідає власним потребам, допомагає людині відчувати задоволеність від життя в аспектах: вміння насолоджуватися відпочинком, задоволення від високої динаміки життя. Економічний оптимізм також дозволяє відчувати задоволення від досягнення поставлених иілей. Результати дослідження дозволяють наголосити на важливості розробки спеціальних програм для розвитку фінансової грамотності, своєчасного формування позитивних установок щзодо грошей підлітків та юнаків.

Ключові слова: ставлення до грочей, монетарна сочіалізачія, монетарна поведінка, задоволеність життям, щуастя, кохання, молодь.
\end{abstract}

Постановка проблеми. Питання про те, що впливає на переживання людиною задоволеності своїм життям, у чому проявляється прагнення до щастя і чи насправді переживання щастя залежить від рівня доходів здавна $є$ предметом уваги багатьох дослідників. Ця тема є міждисциплінарною і розкривається у працях економістів, демографів та психологів. Проте значна кількість публікацій стосується населення Північної Америки та Західної Свропи. В Україні, незважаючи на важливість прикладного аспекту цієї проблеми, вона є мало розробленою. Актуальність подальших досліджень психологічних аспектів ставлення до грошей, монетарної соціалізації, монетарних цінностей зумовлена також суттєвими змінами в економіці країни, нестабільністю у сфері соціальноекономічних відносин та крахом попередньої системи цінностей суспільства.

Аналіз останніх досліджень. Для оцінки рівня задоволеності життям у різних країнах використовується «індекс благополуччя» (Well-Being Index), розроблений організацією Gallup. В основі дослідження - опитування з використанням шкали Кентріла. Питання, на яке відповідають громадяни різних країн, сформульоване таким чином: «Уявіть сходинки, що пронумеровані від 0 (знизу) до 10 (вгорі). Верхня сходинка - це найкраще можливе для вас життя, нижня - це найгірше можливе життя. На якій сходинці, за вашими відчуттями, ви перебуваєте зараз?» [8]. Ортіс та Розер на основі аналізу кроскультурних досліджень з використанням шкали Кентріла приходять до висновків, що респонденти 3 більш економічно благополучних країн оцінюють себе як більш щасливих, задоволених у порівнянні з респондентами 3 економічно нестабільних країн. Такі результати не однозначні і вимагають роз'яснення. У працях нобелівського лауреата 2015 року Енгуса Дітона доведено, що задоволеність життям (у гедоністичному аспекті - переживання щастя, 
радості) залежить від рівня доходів лише до певної межі. Станом на 2010 рік ця межа становила 75 тисяч доларів на рік. Якщо сума доходів вища за названу суму, залежності між збільшенням доходів та підвищенням рівня щастя не спостерігається (за Длугопольським). Розгляд питання лише з економічно-раціональної точки зору не дає змоги глибше розглянути всю глибину суб'єктивних переживань людини щодо грошей та впливу грошових установок на задоволеність життям.

У психологічній площині фокус уваги дослідників зосереджений на питаннях ставлення до грошей, монетарній поведінці, монетарних цінностях. Новітні вітчизняні публікації належать В. Никоненко, В. Мяленко, М. Сімків, А. Шамне [3; 4; 6].

Формування в особистості ставлення до грошей - невід'ємна частина монетарної соціалізації, в ході якої засвоюються також монетарні цінності, монетарні мотиви, монетарні норми, монетарні домагання особистості, стратегії монетарної поведінки [3].

Ставлення до грошей реалізується через монетарну поведінку. Це економічно-фінансова поведінка, що включає в себе роботу виключно з грошовими ресурсами на основі установок і правил поводження з грошима, які вже сформувалися в конкретної особи. Монетарна поведінка є процесом дій, вчинків, а також реалізується в результаті процесів ухвалення рішень стосовно грошей. На монетарну поведінку впливають культурні особливості тієї місцевості, в якій виховується та проживає людина; значною мірою на формування монетарної поведінки впливають поведінкові патерни найближчого оточення людини.

В. Хащенко зазначав, що тип монетарної поведінки буде змінюватися залежно від ставлення особистості до грошей. 3 погляду гармонійної монетарної поведінки, гроші повинні виступати знаряддям для досягнення певних цілей, таких як комфортне існування, високий рівень життя, саморозвиток та інше, але при цьому самі гроші не $\epsilon$ запорукою абсолютного щастя і самоціллю, до якої потрібно прагнути [5].

У роботі І. Зубіашвілі проаналізовано ставлення до грошей українських школярів. Авторка з'ясувала, що серед старшокласників переважає позитивне або нейтральне ставлення до грошей (57,7\% респондентів), у 42,3\% виражені негативні монетарні установки [2].

Суттєво впливають на ставлення до грошей певні особистісні установки. Вивченням таких грошових соціальних установок, які формують нашу фінансову спроможність, займалися К. Ямаучі, Б. А. Спасєнніков, Д. Темплер, І. Рєзвова, Х. Голдберг, Р. Льюіс та інші. Люди наділяють гроші певним позитивним або негативним значенням залежно від того, як говорили про гроші їхні батьки, друзі, знайомі, телебачення та інші джерела. Для когось нестача грошей стане відправною точкою та рушієм розвитку, виникне бажання заробляти більше, а для когось найменша нестача фінансів стане крахом його самоцінності і втратою життєвих орієнтирів.

У роботі Л. Фалагаті представлені результати порівняльного дослідження грошових установок чоловіків та жінок. Автор констатує, що чоловіки ставляться до грошей як до джерела влади і престижу, як інструменту впливу на інших. Чоловіки частіше стурбовані і напружені з приводу грошей, їх непокоїть власне фінансове становище. Натомість жінки демонструють консервативні установки щодо грошей, ставляться до грошей врівноважено, використовують гроші для самопідтримки і зняття стресу [7].

Метою статті $\epsilon$ представлення результатів емпіричного дослідження зв'язку задоволеності життям зі ставленням до грошей осіб юнацького віку.

Методика та процедура дослідження. Здійснивши теоретичний аналіз літератури на тему задоволеності життям та ставлення до грошей, ми виокремили критерії та емпіричні показники, які будуть досліджуватися, і підібрали психодіагностичний інструментарій. Методиками дослідження стали: тест «Індекс задоволеності життям» в адаптації Н. В. Паніної; тест «Діагностика задоволеності життям» А. Б. Білоусової; опитувальник «Суб' єктивне економічне благополуччя» В. А. Хащенко; методика «Шкала грошових уявлень та поведінки» в модифікації М. В Сімків. Загальний обсяг вибірки склав 46 осіб віком від 18 до 22 років, вибірка врівноважена за статтю, всі респонденти мають досвід 
самостійного заробітку. Психодіагностичний етап дослідження проводився 3 використанням програми Google Docs, обрахунок даних здійснювався за допомогою програмного забезпечення SPSS Statistic. Методом математичної статистики, що є релевантним поставленій меті, є метод кореляційного аналізу.

Аналіз результатів дослідження. Результати кореляційного аналізу представлені в таблиці 1.

Таблиия 1

Кореляції між показниками ставлення до грошей та задоволеності життям

\begin{tabular}{|c|c|c|}
\hline $\begin{array}{c}\text { Показники задоволеності } \\
\text { життям }\end{array}$ & Показники ставлення до грошей & $\begin{array}{c}\text { Коефіціент кореляції/ } \\
\text { рівень значущості }\end{array}$ \\
\hline \multirow{3}{*}{ Загальний фон настрою } & Грошова одержимість & $-0,375(p \leq 0,01)$ \\
\hline & Неадекватна поведінка з грошима & $-0,429(p \leq 0,01)$ \\
\hline & Економічний оптимізм & $0,401(\mathrm{p} \leq 0,01)$ \\
\hline $\begin{array}{c}\text { Узгодженість між } \\
\text { поставленими та досягнутими } \\
\text { цілями }\end{array}$ & Неадекватна поведінка з грошима & $-0,495(p \leq 0,001)$ \\
\hline Задоволеність відпочинком & Економічний оптимізм & $0,450(\mathrm{p} \leq 0,01)$ \\
\hline Висока динаміка життя & Економічний оптимізм & $0,450(\mathrm{p} \leq 0,01)$ \\
\hline \multirow{3}{*}{ Кохання } & Неадекватна поведінка з грошима & $-0,385(\mathrm{p} \leq 0,01)$ \\
\hline & Достаток фінансів & $0,465(p \leq 0,001)$ \\
\hline & Гроші як влада & $-0,443(p \leq 0,01)$ \\
\hline Досягнення цілей & $\begin{array}{c}\text { Суб'єктивна адекватність доходів } \\
\text { потребам особистості }\end{array}$ & $0,395(\mathrm{p} \leq 0,01)$ \\
\hline
\end{tabular}

Проаналізуємо отримані результати. 3'ясувалося: що більше у людини виражена одержимість грошима, то нижчий у неї загальний фон настрою. Це означає, що молоді люди, які постійно відчувають потребу у грошах, постійно розмірковують, як примножити i накопичити фінанси, для яких заробіток і накопичення фінансів стають надцінною ідеєю, будуть постійно перебувати у стані пониженого настрою. Висловимо припущення, що респонденти з високим рівнем грошової одержимості переконані, що щасливими і радісними вони можуть бути лише тоді, коли, у них «достатньо фінансів». 3 іншого боку, що менша грошова одержимість, то кращий загальний фон настрою. Людина, що спокійно ставиться до грошей, не оцінює гроші як єдиний ресурс у житті, має самооцінку, незалежну від фінансових статків, найвірогідніше має задоволення від процесу життя.

Також із загальним фоном настрою пов'язана здатність людини адекватно поводитися з грошима, контролювати власні фінансові потоки. Люди, що демонструють виважену фінансову поведінку, можуть запланувати бажані покупки і відпочинок, чим забезпечують собі гарний емоційний стан.

Нездатність контролювати витрати, схильність до спонтанних покупок може призводити до витрачання більше від запланованих сум чи необдуману купівлю в кредит. Можливо, спочатку покупка приносить задоволення, проте з часом це може призводити до фрустрації, до розвитку почуття провини, постійних сумнівів та самозвинувачення, що зрештою значно знижує емоційний фон. Адекватна поведінка щодо витрат, зважене ухвалення рішень щодо необхідних покупок позбавляють людину частини негативних емоцій, що позитивно відображається на ії настрої.

Високий економічний оптимізм підвищує загальний емоційний тонус. Той, хто оптимістично налаштований щодо свого фінансового теперішнього та майбутнього становища, буде почуватися піднесеним та задоволеним власним життям. В розмовах і діях таких людей будуть переважати позитивні настрої, а будь-яка невдача буде сприйматися як активний заклик до дій. Люди з високим економічним оптимізмом не схильні впадати у депресивний стан при втраті грошей, бо для них кожна втрата - новий старт. 3 іншого боку, людина, що в принципі проживає своє життя із задоволенням, у гарному емоційному настрої, буде відчувати більший оптимізм з приводу свого фінансового становища. 
Також було встановлено: що більше людина демонструє неадекватну поведінку 3 грошима, то менш помітна в іiї житті узгодженість між поставленими та досягнутими цілями. 3 цього слідує, що люди, які не вміють контролювати свої витрати, часто відчувають провину через витрачені кошти, не зможуть слідувати власним цілям, бо постійно будуть відволікатися на дрібні промахи. У якості пояснення можна також припустити, що причиною неадекватної поведінки 3 грошима $є$ нездатність людини проникливо розмірковувати і передбачати наслідки своїх дій у перспективі, що також слугує причиною розбіжності між поставленими та досягнутими цілями, проте це припущення потребує подальших досліджень.

Високий рівень економічного оптимізму пов'язаний з високою динамікою життя. Респонденти, що в цілому позитивно передбачають своє економічне майбутнє, налаштовані діяти, досягати успіху, відкриті до змін і будуть уникати застою і рутинізації свого життя.

Встановлено зв'язок економічного оптимізму та задоволеності власним відпочинком. Даний зв'язок свідчить, що люди, які впевнені у власному матеріальному становищі у теперішньому і майбутньому, можуть дозволити собі з насолодою відпочивати. За умови оптимістичного економічного настрою вони розуміють значення якісного відпочинку, не жаліють для нього коштів. Перебуваючи на відпочинку, вони, як правило, можуть дійсно переключитися і відволіктися від робочих задач.

Низку цікавих кореляцій зафіксовано між задоволеністю життям у сфері кохання та показниками ставлення людини до грошей. Люди, які демонструють неадекватну поведінку $з$ грошима, незадоволені своїми стосунками 3 коханими людьми. Тут можна припустити наступне пояснення. Людина, що неадекватно і неспокійно поводиться з грошами, турбується 3 приводу грошей, робить необдумані покупки і часто переживає провину, скоріше за все схожу модель стосунків переносить і в інші сфери життя, внаслідок чого не може побудувати стабільні партнерські стосунки і відчуває себе безталанною в коханні. Що більш адекватно людина поводиться з грошима, то більше вона відчуває задоволеність у сфері кохання.

Так само негативно відбивається на задоволеності у коханні ставлення до грошей як до джерела влади. Що більше людина проявляє схильність використовувати гроші як важіль впливу на інших, то більша вірогідність, що іiї суб'єктивна оцінка задоволеності власними любовними стосунками буде на низькому рівні. Кожному, хто надає грошам занадто велику роль у власному житті і думає, що вони роблять його сильним, буде важко будувати здорові стосунки з іншими. Якщо людина має переконання, що за гроші можна купити все, включаючи дружбу і кохання, ій важко довіряти іншій людині та позбутися підозри, що партнер цінує іiї тільки через гроші.

Наступна кореляція демонструє: що більше людина задоволена власним фінансовим достатком, то більше вона задоволена життям у сфері кохання. Людина, яка має впевненість у своєму фінансовому становищі, скоріш за все є привабливою для партнера, оскільки $з$ такою людиною можна будувати довготривалі стосунки. Така людина знає, що у неї є накопичення, тому частіше вона зможе дарувати партнеру подарунки, що є одним iз проявів мови кохання. Звісно, успіх у коханні залежить не тільки від коштів, які витрачаються на те, щоб завоювати прихильність свого обранця чи обраниці, але завжди існує період, коли у стосунках є період залицяння - присутні квіти, вечері в ресторанах, пікніки на природі, і все це може дозволити собі людина, яка впевнена у своєму фінансовому достатку.

Ще одна кореляція засвідчує, що високий рівень суб' єктивної адекватності доходів потребам особистості підвищує здатність людини досягати поставлених цілей. Ті респонденти, які відчувають, що їхні доходи відповідають їхнім потребам, ставлять у житті реальні цілі і можуть їх досягти. Такі респонденти почуваються фінансово незалежними від інших, будуть ставити перед собою лише ті цілі, які вони реально бажають досягти. 
Вони також почуваються самодостатніми, і це дає впевненість у тому, що всього в житті можна досягти, якщо цього захотіти і прикласти максимум зусиль.

Висновки та перспективи подальшого дослідження. Проведене дослідження дозволило зафіксувати актуальний стан економічної свідомості сучасної молоді в аспекті ставлення до грошей та їх зв'язку з показниками задоволеності життям. Негативна валентність установок щодо грошей (грошова одержимість, неадекватна поведінка з грошима, сприйняття грошей як інструменту влади і впливу) погіршує переживання задоволеності життям у різних сферах. Натомість економічний оптимізм, спокійне і зважене ставлення до грошей, відчуття того, що власний достаток відповідає власним потребам, допомагає людині відчувати задоволення від життя.

Проведене дослідження також актуалізує практично значуще питання про необхідність розробки програм з підвищення фінансової грамотності для школярів та студентів. Формування позитивного ставлення до грошей, монетарних цінностей, а також виявлення та корекція негативних установок у перспективі слугуватимуть підвищенню показників переживання задоволеності життям.

Зважаючи на велику кількість показників задоволеності життям, подібне дослідження є перспективним. Відкритими залишились питання про гендерні, вікові особливості ставлення до грошей.

1. Длугопольський, О. (2015). Ангус Дітон про споживання, доходи та задоволення від життя. Bicник Тернопільського національного економічного університету, 4, 149-163.

2. Зубіашвілі, І. (2008). Соціально-психологічна сутність грошей. Соиіальна психологія, 1 (27), 128-141.

3. Никоненко, О. В. (2005). Психологічні особливості монетарної соціалізації майбутніх фахівців. Вісник післядипломної освіти. Збірник наукових праџь, 9 (22), 239-246.

4. Сімків, М. (2010). Соціально-психологічні аспекти ставлення до грошей. Соціогуманітарні проблеми науки, 5, 209-217.

5. Хащенко, В. А., Баранова, А. В. (2004). Взаимосвязь оценки качества жизни и экономикопсихологического статуса личности. Проблемы экономической психологии, 1, 501-527.

6. Шамне, А. В. (2018). Ставлення до грошей, монетарні установки і цінності сучасної молоді України Проблеми сучасної психології. 1, 189-195.

7. Falahati, L. A. (2011). Comparative Study in Money Attitude among University Students: A Gendered View. Journal of American Science, 6(3), 1144-1148.

8. Ortiz-Ospina E., Roser M. (2019). Happiness and Life Satisfaction. Published online at OurWorldInData.org. Retrieved from https://ourworldindata.org/happiness-and-life-satisfaction.

\section{REFERENCES}

1. Dluhopolskyi, O. (2015). Anhus Diton pro spozhyvannia, dokhody ta zadovolennia vid zhyttia [Angus Deaton about consumption, incomes and happiness]. Visnyk Ternopilskogo nacionalnogo ekonomichnogo universytetu [The Herald of Ternopil National Economic University], 4, 149-163. (ukr.).

2. Zubiashvili, I. (2008). Sotsialno-psykholohichna sutnist hroshei [Socio-psychological essence of money]. Sotsialna psykholohiia [Social psychology], 1 (27), 128-141. (ukr.).

3. Nykonenko, O. V. (2005). Psykholohichni osoblyvosti monetarnoi sotsializatsii maibutnikh fakhivtsiv [Psychological peculiarities of monetary socialization of future specialists]. Visnyk pisliadyplomnoi osvity. Zbirnyk naukovykh prats [The Herald of postgraduate education. Collection of scientific works], 9 (22), 239-246. (ukr.).

4. Simkiv, M. (2010). Sotsialno-psykholohichni aspekty stavlennia do hroshei [Socio-psychological aspects of the attitude to money]. Sotsiohumanitarni problemy nauky [Socio-humanitarian problems of science], 5, 209-217. (ukr.).

5. Khashchenko, V. A., Baranova, A. V. (2004) Vzaymosviaz otsenky kachestva zhyzny y эkonomykopsykholohycheskoho statusa lychnosty [The assessing the quality of life and the economic and psychological status of the individual]. Problemy ekonomycheskoi psykhologii [Problems of economic psychology], 1, 501-527. (rus.).

6. Shamne, A. V. (2018). Stavlennia do hroshei, monetarni ustanovky i tsinnosti suchasnoi molodi Ukrainy [Attitude to money, monetary settings and values of modern Ukrainian youth]. Problemy suchasnoi psykholohii [Problems of modern psychology], 1, 189-195. (ukr.).

7. Falahati, L. A. (2011). Comparative Study in Money Attitude among University Students: A Gendered View. Journal of American Science, 6(3), 1144-1148.

8. Ortiz-Ospina, E., Roser, M. (2019). Happiness and Life Satisfaction. Published online at OurWorldInData.org. Retrieved from https://ourworldindata.org/happiness-and-life-satisfaction. 


\section{LIFE SATISFACTION AND ATTITUDE OF YOUNG PEOPLE}

The connection of life satisfaction with the attitude towards money in young people is analyzed in this article. There is one of the most studied question: does happiness and life satisfaction depend on incomes. This question is relevant for nowadays on account of changes in the monetary values of modern Ukrainian youth. The research procedure using the four methods is described such as «Index of Life Satisfaction» (N. Panina), «Test of the diagnosis of satisfaction with life» (A. Belousova), «Subjective economic well-being» (V. Khaschenko), «The scale of monetary representations and behavior» (M. Simkiv). According to the results of the empirical research, it was found that the negative money settings (monetary obsession, inadequate behavior with money, perception of money as a tool of power and influence) worsen the emotional component of life satisfaction (mood), reduce satisfaction with life in the sphere of love. Economic optimism, calm and balanced attitude towards money, feeling that your own abundance corresponds one's own needs helps a person to feel satisfied with life, and achieve of the set goals. The results of the research allow emphasizing the importance of developing special programs for the development of financial literacy for teens and young people.

Keywords: attitudes to money, monetary socialization, monetary behavior, satisfaction with life, happiness, love, youth. 